\title{
Seasonal occurrence and hatching of calanoid eggs in sediments of the northern Baltic Sea
}

\author{
Tarja Katajisto $^{1,2, *}$, Markku Viitasalo ${ }^{2,3}$, Marja Koski $^{2,3}$ \\ ${ }^{1}$ Finnish Institute of Marine Research, PO Box 33, FIN-00931 Helsinki, Finland \\ ${ }^{2}$ Tvärminne Zoological Station, FIN-10900 Hanko, Finland \\ ${ }^{3}$ Department of Ecology and Systematics, Division of Hydrobiology, Box 17, FIN-00014 University of Helsinki, Finland
}

\begin{abstract}
The seasonal occurrence and hatching of benthic eggs of calanoid copepods were studied for $1 \mathrm{yr}$ in the surface sediments at 2 sites (a $33 \mathrm{~m}$ deep archipelago area and a $42 \mathrm{~m}$ deep site in an enclosed bay) off the SW coast of Finland, northern Baltic Sea. Eggs were abundant at both sites (up to 4 and $6 \times 10^{6}$ eggs $\mathrm{m}^{-2}$ ). At the archipelago site, most eggs belonged to Acartia bifilosa and A. tonsa; at the bay site, eggs of Eurytemora affinis and Acartia spp. occurred. At the archipelago site, the egg numbers in the surface sediment followed closely the seasonal abundance of the planktonic Acartia spp. females. The eggs collected from the sediment were incubated at temperatures corresponding to the in situ bottom temperatures. Hatching of the $A$. bifilosa eggs occurred throughout the year, but it was most intensive in autumn when water stratification broke and the deep water warmed up to $13^{\circ} \mathrm{C}$. It is suggested that a large number of the $A$. bifilosa eggs sink to the bottom prior to hatching in shallow coastal areas of the Baltic Sea. Hatching of the benthic eggs occurs throughout the year and the rate of naupliar emergence from the sediments depends on benthic conditions and processes (e.g. temperature, sediment resuspension and bioturbation). At the bay site, where the surface water layer was hydrographically separated from the deep water, the coupling between the benthic egg abundance and the planktonic populations was not so obvious. The dominant species $E$. affinis carries its eggs in an egg sac until hatching, and probably only the diapause eggs, which are produced in autumn, fall to the bottom. A. tonsa was abundant in the water column at both study sites in autumn, even outnumbering other Acartia spp. in some samples. The eggs of the species only hatched in autumn, when the incubations were conducted at 10 to $13^{\circ} \mathrm{C}$. It is probable that $A$. tonsa spends most of the year as benthic resting eggs in the northern Baltic Sea. In contrast, $A$. bifilosa and $E$. affinis occurred in the plankton in winter at both study sites, though in low concentrations. They thus have 2 possible sources of recruitment when conditions are again favourable for population growth in spring: hatching of benthic eggs and reproduction by the overwintering population.
\end{abstract}

KEY WORDS: Calanoida - Acartia bifilosa - Acartia tonsa - Eurytemora affinis - Resting eggs - Benthicpelagic coupling $\cdot$ Baltic Sea

\section{INTRODUCTION}

The seasonal dynamics of planktonic biota in coastal areas is often accompanied by benthic-pelagic coupling. A variety of planktonic animals (e.g. Reid \& John 1978, Grice \& Marcus 1981, Onbé 1985) and algae (e.g. Fryxell 1983) spend part of their life cycles as benthic resting stages, and many principally benthic organisms make a seasonal appearance in the plankton as larvae (Williams \& Collins 1986). The successive

•E-mail: tarja.katajisto@helsinki.fi blooms of primary and secondary producers in coastal marine pelagial environments can, thus, often be viewed as dynamics of emergence from the bottom (Boero 1994). However, seasonality is not the only background to benthic-pelagic coupling in life cycles. In shallow areas, the short distance between the 2 habitats results in coupling when, for instance, eggs released by zooplankton reach the bottom before hatching (Landry 1978, Uye 1980, Lindley 1992). In such areas, the ability of eggs to retain viability in the sediments is essential, and Lindley (1992) even argues that this ability may have allowed centropagid cope- 
pods to maintain populations in near-shore environments as well as to colonize inland waters.

Copepod dormancy may be described in similar terms to that of insects (Watson \& Smallman 1971b, Elgmork \& Nilssen 1978, Grice \& Marcus 1981). 'Quiescence' refers to a state of retarded development as a direct response to adverse environmental conditions, whilst 'diapause' refers to a genetically controlled state of arrested development, triggered by a stimulus preceding the onset of environmental adversity (Grice \& Marcus 1981). In the 'refractory phase' of diapause, development does not resume even under favourable conditions (Watson \& Smallman 1971a). Development and hatching in quiescent and post-refractory diapause eggs may be regulated by seasonally varying conditions, such as temperature (e.g. Kasahara et al. 1975a, Uye et al. 1979, Johnson 1980, Sullivan \& McManus 1986, Marcus 1989). Hatching is also inhibited if eggs are buried under sediment (Kasahara et al. 1975a, Uye et al. 1979, Uye 1980), probably due to the low oxygen concentration (Kasahara et al. 1975a, Uye \& Fleminger 1976, Uye et al. 1979) which typically prevails under the few topmost mm of sediment (e.g. Revsbech et al. 1980).

It is plausible that in the Baltic Sea a large fraction of copepod eggs sink to the bottom before hatching. The sea is very shallow, $57 \%$ of its area being shallower than $50 \mathrm{~m}$. Long development times of eggs are to be expected (cf. McLaren et al. 1969) since the water stays cold $\left(<6^{\circ} \mathrm{C}\right)$ below a depth of $\sim 15 \mathrm{~m}$ during most of the annual cycle. The Baltic Sea is also a strongly seasonal environment, which makes resting egg production a worthwhile strategy for zooplankton. However, the existence and viability of calanoid resting eggs in Baltic sediments were only recently demonstrated (Viitasalo 1992a, Viitasalo \& Katajisto 1994), and their role in the seasonal dynamics of Baltic copepods is still unknown.

The aim of this study was to establish whether there is a detectable seasonality in the numbers and hatching activity of calanoid eggs in surface sediments, and how this is reflected in planktonic population dynamics. The study was carried out in 2 areas differing in hydrographical conditions and sedimentary characteristics.

\section{MATERIALS AND METHODS}

Study area. The sampling area is located on the eastern side of Hanko peninsula, at the entrance to the Gulf of Finland, northern Baltic Sea (Fig. 1). The area represents a transition between open sea water (surface salinity $\sim 6 \%$ ) and the fresh water of the head of Pojo Bay. At the first study site, Storfjärden (depth

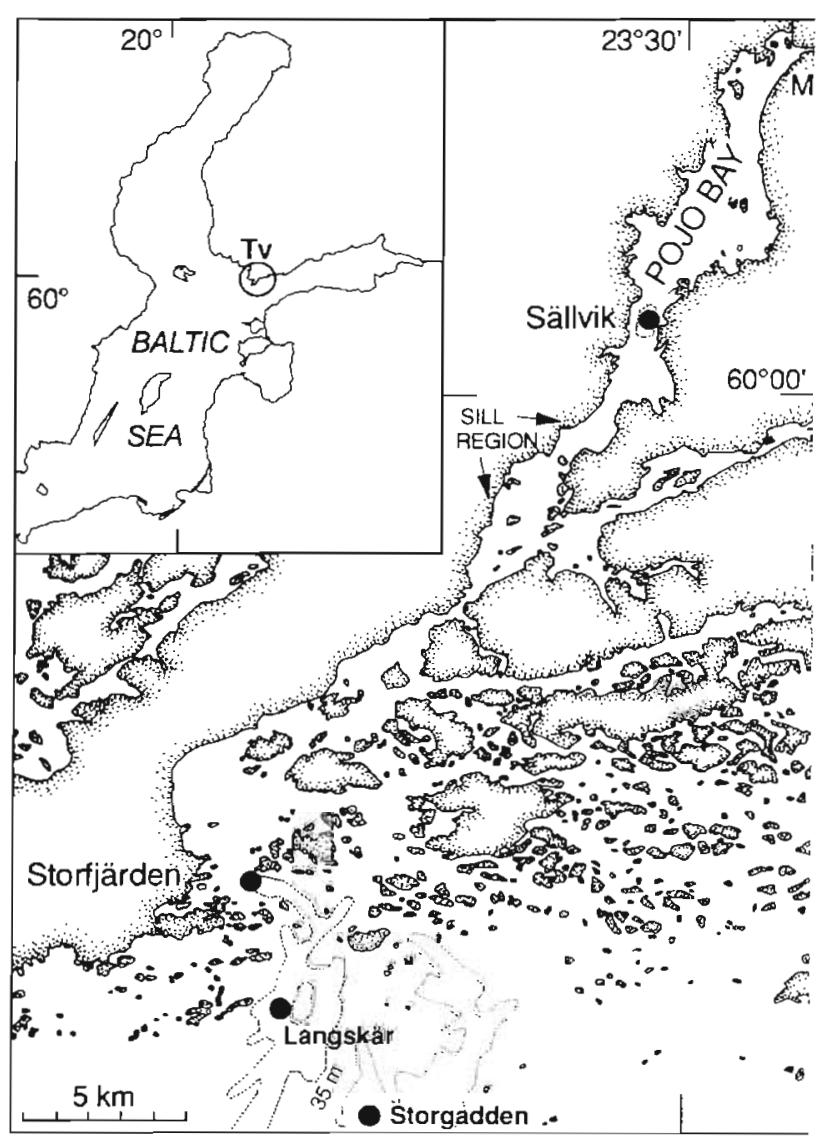

Fig. 1. Study area and sampling sites on the SW coast of Finland. M: River Mustionjoki

$33 \mathrm{~m})$, the bulk of the water column is formed by surface water of the open Baltic proper. Meteorological processes are largely responsible for the variations in hydrographic conditions. Summer stratification of the water column breaks easily. In winter, water temperature near the bottom is below $1^{\circ} \mathrm{C}$ (Niemi 1973, 1975). Ice covers the area for variable periods in winter, but not necessarily every year. The sediment is bioturbated by an abundant benthic fauna, including the amphipod Monoporeia affinis, the isopod Saduria entomon, the bivalve Macoma baltica (Karjala \& Lassig 1985, Finnish Institute of Marine Research unpubl.), and the polychaete Marenzelleria viridis (Stigzelius et al. 1997).

The second study site, Sällvik deep, is in the deepest part (depth $42 \mathrm{~m}$ ) of a long sea inlet, Pojo Bay. A layer of fresh water, mostly originating from the River Mustionjoki, flows on top of the more brackish deep water (4 to $5.5 \%$ ). The resulting halocline at $\sim 10 \mathrm{~m}$ depth effectively prevents mixing of these layers. Renewal of the deep water mostly depends on the occasional inflows of saline water over a $6 \mathrm{~m}$ deep sill, which normally takes place in winter and spring. Ice cover often 
persists from December or January until April. In late summer and autumn the oxygen concentration of the deep water is very low (Niemi 1978), and benthic macrofauna is absent. Due to the lack of bioturbation, the sediments of varying ages do not mix. The brown oxygenated layer extends down to $1-2 \mathrm{~cm}$ depth, and black and grey layers alternate below that (Viitasalo \& Katajisto 1994).

In May 1995, 2 extra sites, Långskär (depth $43 \mathrm{~m}$ ) and Storgadden $(50 \mathrm{~m})$, were sampled. Both lie towards the open sea from Storfjärden.

Plankton sampling and hydrographical measurements. Zooplankton was sampled at 2 to $6 \mathrm{wk}$ intervals between March 1992 and April 1993. The samples were taken with a $100 \mu \mathrm{m}$ mesh net (diameter $60 \mathrm{~cm}$ ), with vertical hauls from $30 \mathrm{~m}$ (Storfjärden) and $37 \mathrm{~m}$ (Sällvik) to the surface. The samples were preserved in $\sim 4 \%$ hexamin buffered formalin. The samples were divided 5 to 9 times with a Folsom splitter (Omori \& Ikeda 1984). For calanoid copepods, the numbers of adults (females and males) and the copepodite stages (I to $V$ ) were counted under a dissecting microscope; the naupliar stages were grouped by size into 3 categories representing stages I to II, III to IV and V to VI. However, the sampling was not quantitative for the smallest nauplii (stages I to II). In these countings, Acartia spp. were grouped together, but the females were given a closer examination later: 50 specimens from most samples were determined to species level (A. bifilosa, $A$. tonsa, $A$. longiremis). At 1 to 2 wk intervals the salinity and temperature profiles were measured by Tvärminne Zoological Station with a SIS CTD plus 100

Sediment sampling and analysis. Sediment was sampled at 2 to 4 wk (once 8 wk) intervals between March 1992 and April 1993. Five replicate samples of the surface sediment ( 1 to $2 \mathrm{~cm}$ thick layer, except during the first sampling at Sällvik, 0 to $1 \mathrm{~cm}$ ) were taken with a Limnos sediment corer (diameter $94 \mathrm{~mm}$; described in Kansanen et al. 1991). In May 1995, 1 sediment core sample per station was taken at Långskär and Storgadden. After sampling the surface with a siphon, four $1 \mathrm{~cm}$ thick slices were cut from the cores from a depth between 0 and $11 \mathrm{~cm}$. All samples were kept in a cool box until they were placed in a temperature-controlled room at $3 \pm 2^{\circ} \mathrm{C}$. Ambient bottom water was sampled and filtered $(\mathrm{GF} / \mathrm{C})$ to be used for processing the samples and for subsequent incubations.

Each replicate sediment sample was divided into 3 subsamples. Before division, the samples were sonicated for 1 min (Bransonic Ultrasonic cleaner B-2200 E3) to break up sediment clots (cf. Marcus 1984a, 1989). Plastic sample containers were filled to a known volume (500 or $800 \mathrm{ml}$ ) with $\mathrm{GF} / \mathrm{C}$ filtered seawater, mixed with a magnetic stirrer, and subsamples were taken with a $50 \mathrm{ml}$ syringe (for the first 4 sampling occasions a Folsom splitter was used for subsampling). The subsamples for quantitative countings $(1 / 5$ or $1 / 4$ of the whole sample) were washed on a $50 \mu \mathrm{m}$ sieve and preserved in $\sim 70 \%$ ethanol. The subsamples for determining the dry weight of the sediment were dried on preweighed glass fibre filters at $60^{\circ} \mathrm{C}$ for $24 \mathrm{~h}$ and placed in a desiccator before weighing with an electronic toploader (Mettler PE 3600, precision $0.01 \mathrm{~g}$ ). The third set of subsamples was stored at $3^{\circ} \mathrm{C}$ until the next day, when eggs were collected for the hatching experiments.

The eggs were counted from 3 replicate samples. They were extracted from the sediment by the sugar flotation method (Onbé 1978). The samples were washed with tap water on a $50 \mu \mathrm{m}$ sieve. The material remaining on the sieve was washed into a centrifugation tube with sugar solution $(1000 \mathrm{~g}$ sucrose in $1000 \mathrm{ml}$ distilled water) and centrifuged at $3000 \mathrm{rpm}$ $(1300 \times g)$ for $3 \mathrm{~min}$. After the centrifugation the supernatant was transferred back to the sieve and the sugar was carefully washed away. The eggs were counted in a counting chamber under a dissecting microscope. In addition, a subsample of the sediment fraction was checked for eggs, because in the samples preserved in ethanol some eggs tended to remain in the sediment during centrifugation.

Hatching experiments. The eggs for the hatching experiments were extracted from the sediments in a similar way to the preserved samples, except that filtered seawater was used for washing. Neither sonication (Marcus 1984a) nor centrifugation (Onbé 1978) should affect the viability of the eggs. Care was taken to keep the samples as cool as possible during all stages of handling. After centrifugation and washing, the eggs were collected with a pasteur pipette onto 96 -well microtitration plates ( 1 egg per well, -50 eggs per replicate sample) and incubated in temperaturecontrolled rooms $\left(3 \pm 2\right.$ or $\left.13 \pm 2^{\circ} \mathrm{C}\right)$ or in a cooled incubator $\left(10^{\circ} \mathrm{C}\right.$, Termaks $)$, depending on the ambient bottom water temperature. In September, when the Storfjärden incubations were conducted at $13^{\circ} \mathrm{C}$, an additional 50 to 100 eggs per sample were incubated as temperature controls in 24 -well culture plates at $3^{\circ} \mathrm{C}$. The incubations were conducted in the dark as light was not expected to have an effect on hatching in situ. Lindström \& Nilsson (1988) could not detect any measurable amounts of light near the bottom around noon in summer at the Storfjärden and Sällvik study sites.

Hatched nauplii and unhatched eggs were counted after $6 \mathrm{~d}$. Nauplii were identified using an inverted microscope, but identification of stage I nauplii was difficult and could not be accomplished for all specimens. 

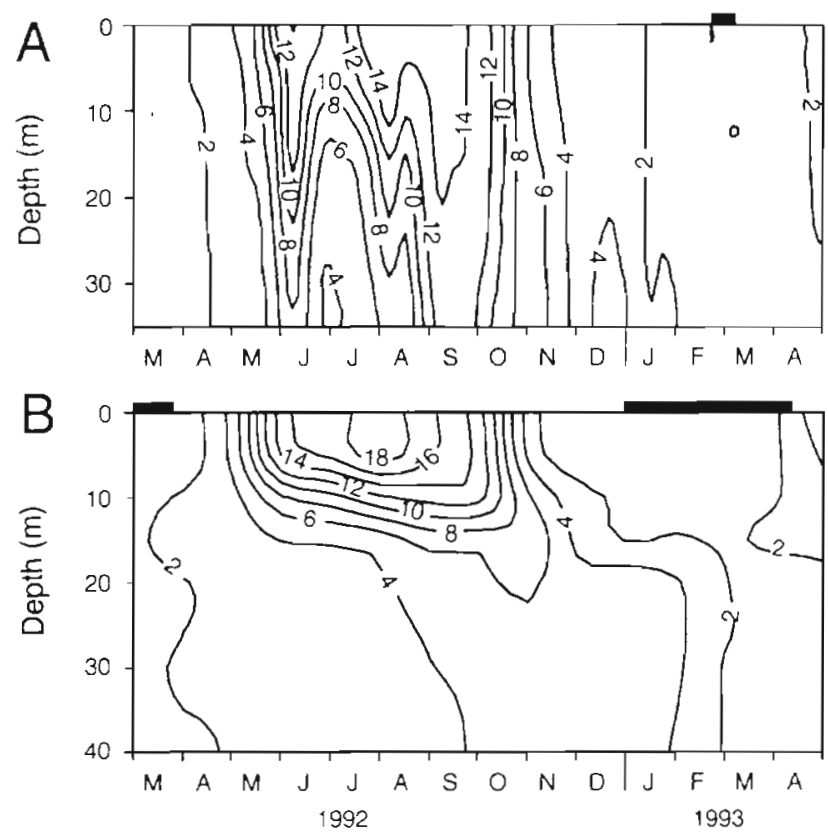

Fig. 2. Temperature development at (A) Storfjärden and (B) Sällvik in March 1992 to April 1993. Horizontal bars denote the approximate duration of ice cover

In May 1995, an additional experiment was conducted to determine the hatching rate of the eggs from sediments at different temperatures. The eggs were extracted from the Långskär and Storgadden sediment samples $1 \mathrm{~d}$ after sampling as described above. After 2 more days at $3^{\circ} \mathrm{C}$ the eggs were picked onto 96 -well microtitration plates $(-3$ eggs per welli $3 \times 12$ wells per sample for each temperature, if there were sufficient numbers of eggs), which were placed in temperaturecontrolled rooms at 3,13 and $18^{\circ} \mathrm{C}$, and the remaining eggs were counted. The incubations were checked daily for hatched nauplii until no more nauplii hatched for several days. Hatching of the eggs during the initial $2 \mathrm{~d}$ storage after extraction at $3^{\circ} \mathrm{C}$ was not considered to significantly bias the results; during the picking, few nauplii were observed in 2 samples only. These $2 \mathrm{~d}$ were added to the calculated mean hatching times at $3^{\circ} \mathrm{C}$ but not at 13 or $18^{\circ} \mathrm{C}$.

Statistical procedure. To investigate the possible correlations and lag periods between the time series of the eggs, nauplii and females of Acartia spp. at Storfjärden, Pearson correlation coefficients were calculated between the mean abundances of eggs in the surface sediment and the nauplii and females in the water column, with different time lags. The analyses were done for the period from March to November 1992, when the samples were collected at $\sim 2$ wk intervals. If the egg and plankton data were not collected during the same weeks, the missing data points were calculated as an average of the 2 nearest data points.
The analyses were performed with SYSTAT statistical package 5.03 .

\section{RESULTS}

\section{Hydrographical conditions}

The temperature development at the study sites in 1992 and 1993 is shown in Fig. 2. Stratification at Storfjärden was weaker and the temperature fluctuated more than at Sällvik, both at the surface and near the bottom. Mixing of the water column warmed the bottom water up to $13^{\circ} \mathrm{C}$ in the autumn at Storfjärden, whilst the bottom water at Sällvik remained relatively cool throughout the year. Storfjärden was free from ice cover in 1992, also prior to the sampling period, and was covered only briefly in 1993 . The bottom water salinity was lower (4 to $5.5 \%$ ) at Sällvik than at Storfjärden ( 5 to $7 \%$ ) (Fig. 3). At the time of the sampling, the temperature and salinity near the bottom were $3.2^{\circ} \mathrm{C}$ and $6.7 \%$ at Storgadden and $4.1^{\circ} \mathrm{C}$ and $5.9 \%$ at Långskär.

\section{Abundance variations in the planktonic populations and the benthic eggs of copepods}

Acartia spp. and Eurytemora affinis (Poppe) were the most abundant copepods at Storfjärden. Other copepods that occurred were the calanoids Temora longicornis (Müller), A. longiremis (Lilljeborg), Limnocalanus macrurus Sars, Pseudocalanus minutus elongatus (Boeck), Centropages hamatus (Lilljeborg), and Cyclopoida spp. At Sällvik the calanoids E. affinis, $L$. macrurus, A. bifilosa, A. tonsa and C. hamatus and the cyclopoids Thermocyclops oithonoides Sars and Mesocyclops leuckarti Claus were found. The dynamics of Acartia spp. and $E$. affinis is described in more detail below.

Acartia spp. occurred in the plankton throughout the year at Storfjärden, although the numbers in winter

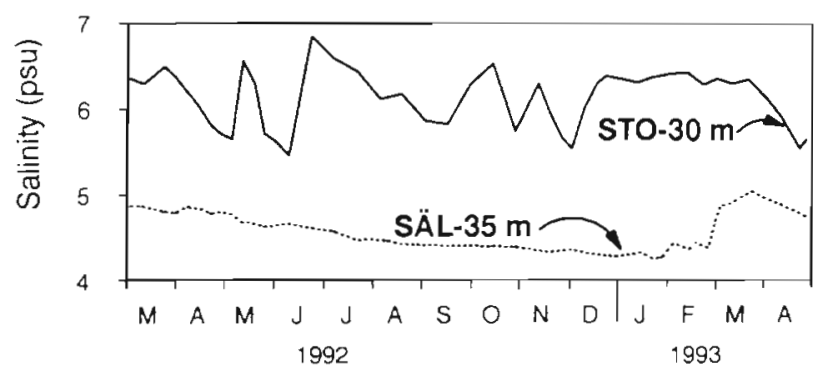

Fig. 3. Salinity of the bottom water layer at Storfjärden (STO$30 \mathrm{~m}$ ) and Sällvik (SÄL-35 m) in March 1992 to April 1993 
were very low (Fig. 4A). The overwintering stages were mainly nauplii and copepodites. Adults peaked for the first time in the middle of May. The numbers of nauplii and small copepodites peaked for the last time in November, but most of them disappeared before reaching adulthood. A. bifilosa was the most numerous of the Acartia spp., but in autumn also $A$. tonsa females became abundant. A. longiremis occurred in early spring, when the total density was low.

Eggs were deposited on the bottom throughout the productive season. Their abundance in the surface sediments at Storfjärden was lowest in spring $\left(6 \times 10^{4}\right.$ eggs $\mathrm{m}^{-2}$ in April 1992) and highest in autumn (up to $6 \times 10^{6}$ eggs $\mathrm{m}^{-2}$ in August and in October) (Fig. 4B). The variations in abundance were largely related to those of planktonic Acartia spp. females (Fig. 4A, B): the egg numbers followed the numbers of the females with a 2 to 6 wk lag ( $\mathrm{r}^{2}$ with 4 and $6 \mathrm{wk}$ lags $\sim 60 \%$; Table 1). The numbers of nauplii in the water column, in turn, correlated both with the abundance of benthic eggs, with a 0 to 4 wk lag ( $\mathrm{r}^{2}$ with $2 \mathrm{wk} \operatorname{lag} 57 \%$ ), and with the abundance of females, with a 4 to $6 \mathrm{wk}$ lag $\left(\mathrm{r}^{2}\right.$ with $6 \mathrm{wk}$ lag $67 \%$ ).

At Sällvik the abundance of Acartia spp. remained very low throughout the year compared to Storfjärden (Fig. 5A). A. bifilosa dominated the females but the relative abundances of $A$. longiremis in spring and A. tonsa in autumn were higher than at Storfjärden. In winter the abundances were not especially low compared to the rest of the

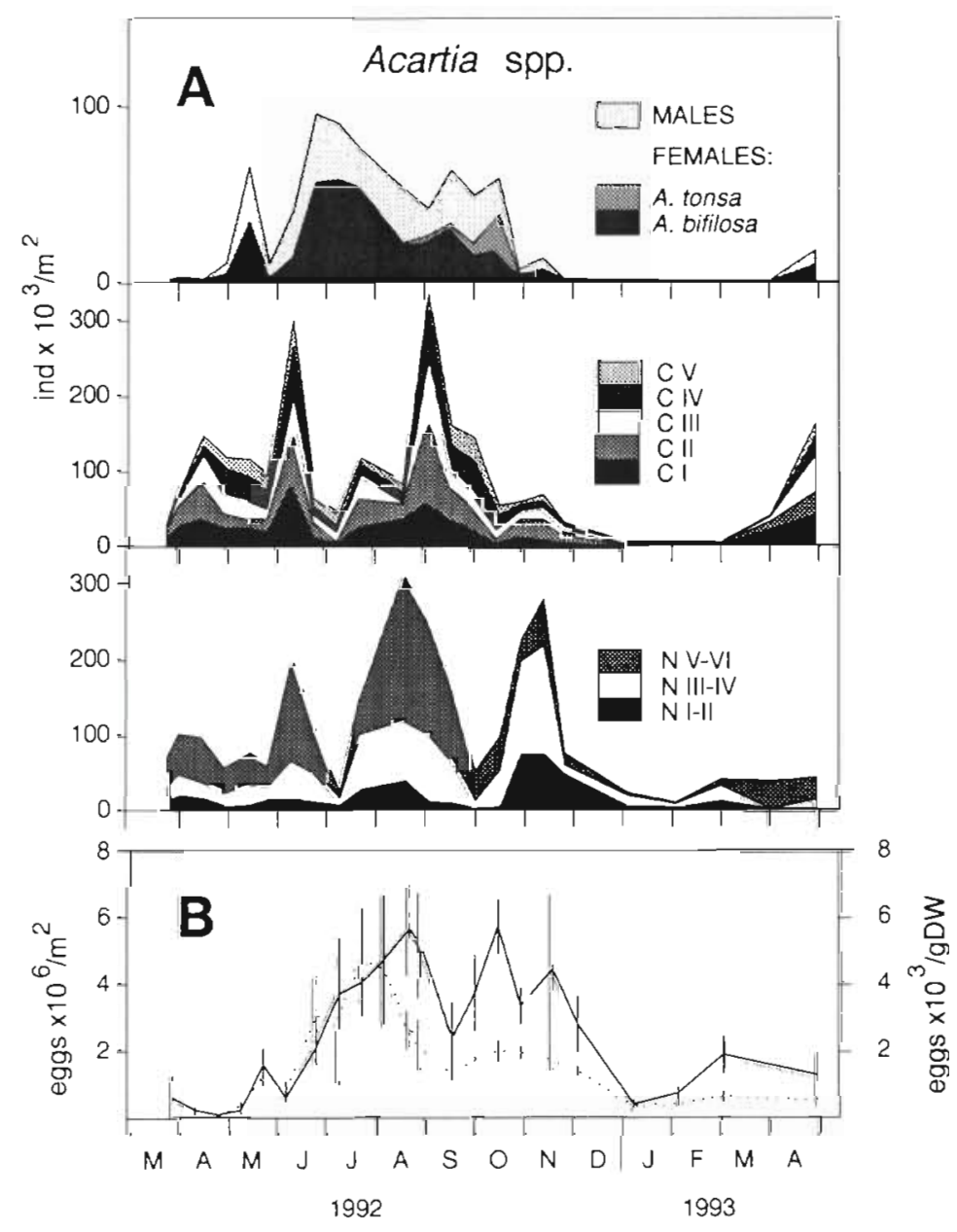

Fig. 4. Calanoida spp. (A) Seasonal abundance variations in Acartia spp. in the water column at Storfjärden in 1992 and 1993. Note that 'adults' are presented in a different scale from the other stages. N: nauplii; $C$ : copepodites. (B) Seasonal abundance (-) of calanoid eggs in the surface sediment ( 1 to $2 \mathrm{~cm}$ thick) at Storfjärden in 1992 and 1993, and abundance corrected with DW of the sediment sample $(\cdots)$; means and standard deviations of 3 replicates
Table 1. Acartia spp. Pearson correlation coefficients ( $r$ ) between the time series of nauplii in the water column, eggs in the surface sediment and females in the water column, in March to November 1992, with different lag periods, $t_{0}-2 \mathrm{wk}$, $t_{0}-4 \mathrm{wk}$ and $t_{0}-6 \mathrm{wk}$ denote 2,4 and $6 \mathrm{wk}$ lags, respectively. ns: not significant; $\cdot 0.01<\mathrm{p}<0.05 ; \cdots 0.001<\mathrm{p}<0.01 ; \cdots \mathrm{p}<$ 0.001 . Only a part of the correlation matrix shown. $N=15$ for each correlation

\begin{tabular}{|lrrrr|}
\hline & Benthic eggs, $t_{0}$ & Nauplii, $t_{0}$ \\
\hline Benthic eggs, $t_{0}$ & & & 0.556 & $\cdot$ \\
Benthic eggs, $t_{0}-2 \mathrm{wk}$ & & & 0.753 & $\cdots$ \\
Benthic eggs, $t_{0}-4 \mathrm{wk}$ & & & 0.671 & $\cdots$ \\
Benthic eggs, $t_{0}-6 \mathrm{wk}$ & & & 0.354 & $\mathrm{~ns}$ \\
Females, $t_{0}$ & 0.174 & $\mathrm{~ns}$ & -0.287 & $\mathrm{~ns}$ \\
Females, $t_{0}-2 \mathrm{wk}$ & 0.563 & $\cdot$ & -0.147 & $\mathrm{~ns}$ \\
Females, $t_{0}-4 \mathrm{wk}$ & 0.767 & $\cdots$ & 0.711 & $\cdots$ \\
Females, $t_{0}-6 \mathrm{wk}$ & 0.778 & $\cdots$ & 0.821 & $\cdots$ \\
\hline
\end{tabular}

year. Mainly the nauplii overwintered; in late winter the copepodites also increased in abundance. The total abundance of Eurytemora affinis remained relatively low throughout the year except in September and October (Fig. 5B). The nauplii showed 4 distinctive peaks, and the copepodites were most abundant in autumn. The adults were relatively abundant throughout the summer until November. The adults made up $\sim 50 \%$ of the overwintering population and the copepodites outnumbered the nauplii. By the end of April the nauplii and early copepodite stages became abundant.

No clear seasonal trend was manifested in the Sällvik egg abundances (Fig. 5C). High abundances were attained in summer and again in late autumn, maximum $4 \times 10^{6}$ eggs $\mathrm{m}^{-2}$ in the 1 to $2 \mathrm{~cm}$ thick surface layer. The decline in abundance in September coin- 

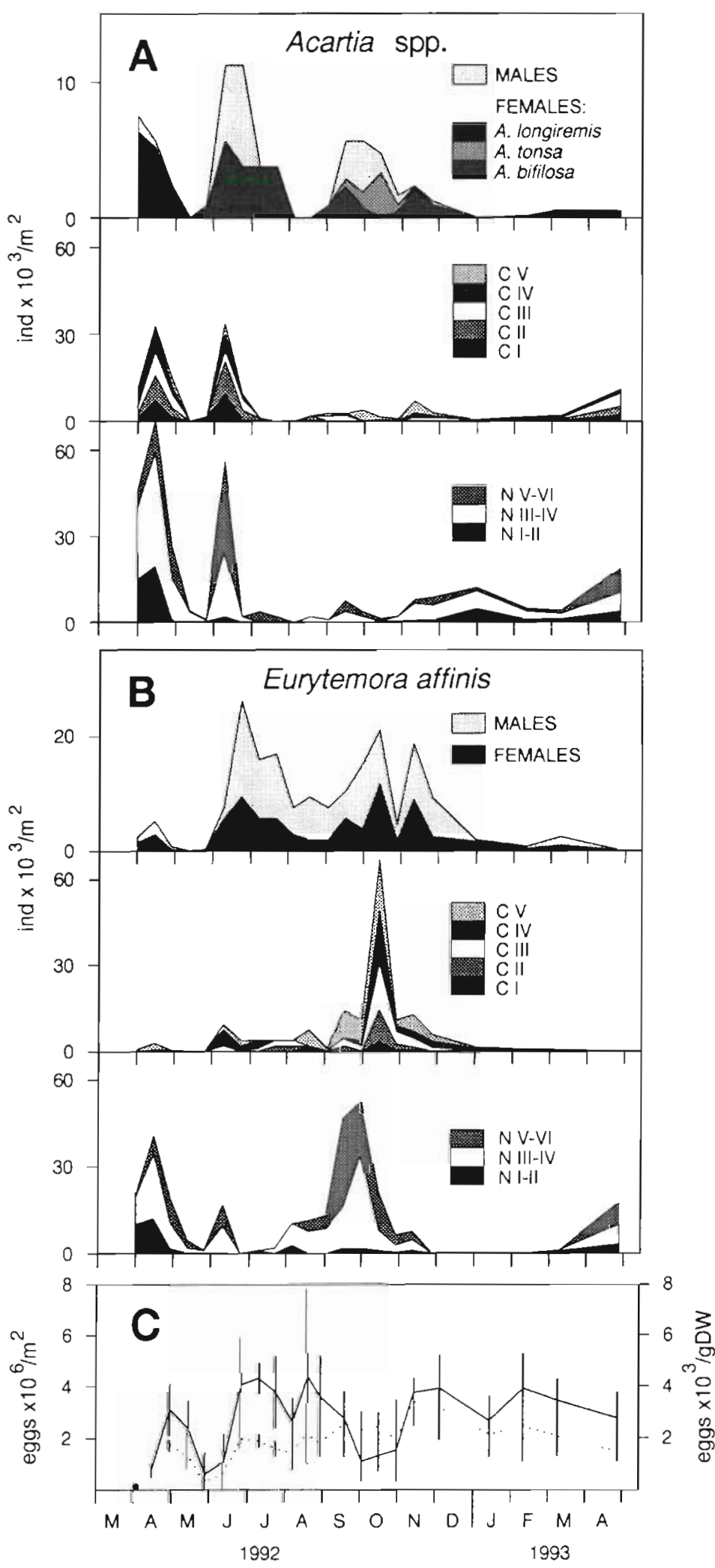

Fig. 5. Calanoida spp. Seasonal abundance variations in (A) Acartia spp. and (B) Eurytemora affinis in the water column and (C) calanoid eggs in the surface sediment $[1$ to $2 \mathrm{~cm}$ thick; $(\bullet) 0$ to $1 \mathrm{~cm}$ ] at Sällvik in 1992 and 1993. Other notation as in Fig. 3 cided with the decline in the sediment dry weight, which was due to an accumulation of newly sedimented, loose material. Correspondingly, no simultaneous decline occurred in the egg numbers corrected for sediment dry weight.

\section{Hatching of the benthic eggs}

Nauplii of Acartia spp, and Eurytemora affinis hatched from the benthic eggs. Nauplii that could not be identified are also assumed to belong to one of these taxa, since no other species has been observed to hatch from the benthic eggs in the study area in any later studies either.

There were 2 more or less distinguishable egg types among the benthic eggs: eggs with red or violet pigmentation (diameter 78 to $86 \mu \mathrm{m}$ ) and whitish eggs (diameter 80 to $91 \mu \mathrm{m}$, sometimes with a light blue or green appearance) which were often covered with attached material. The occurrence of intermediate egg colours and the overlap in size made classification difficult. Later comparisons of these egg types with eggs produced by Acartia bifilosa, A. tonsa and Eurytemora affinis suggest that the 'red' eggs belonged to $A$. bifilosa and the 'white' eggs to $A$. tonsa and/or E. affinis. At Storfjärden the benthic eggs were mostly of the 'red' type until the end of September, when both types cooccurred. After that, these types were incubated separately. At Sällvik no such distinction into separate types was made Unfortunately, the red colour disappeared from the eggs in the preserved samples and the egg types were not distinguished in the abundance data.

At Storfjärden Acartia spp. nauplii hatched from the benthic eggs (the 'red' type, $A$ bifilosa) throughout the year (Fig. 6A). In March to August 1992, 18 to $49 \%$ of the eggs hatched in $6 \mathrm{~d}$ at $3^{\circ} \mathrm{C}$. When the deep water temperature increased up to $13^{\circ} \mathrm{C}$ in Septem. ber, the incubation temperature was correspondingly raised. This resulted in a clearly larger ( 83 to $92 \%$ ) proportion of the eggs hatching in $6 \mathrm{~d}$. In simultaneous control incubations at $3^{\circ} \mathrm{C}$ in September only 20 to $30 \%$ of the eggs hatched. After that, until April 1993, the incubations were again performed at $3^{\circ} \mathrm{C}$, with hatching percentages ranging from 13 to $27 \%$. 


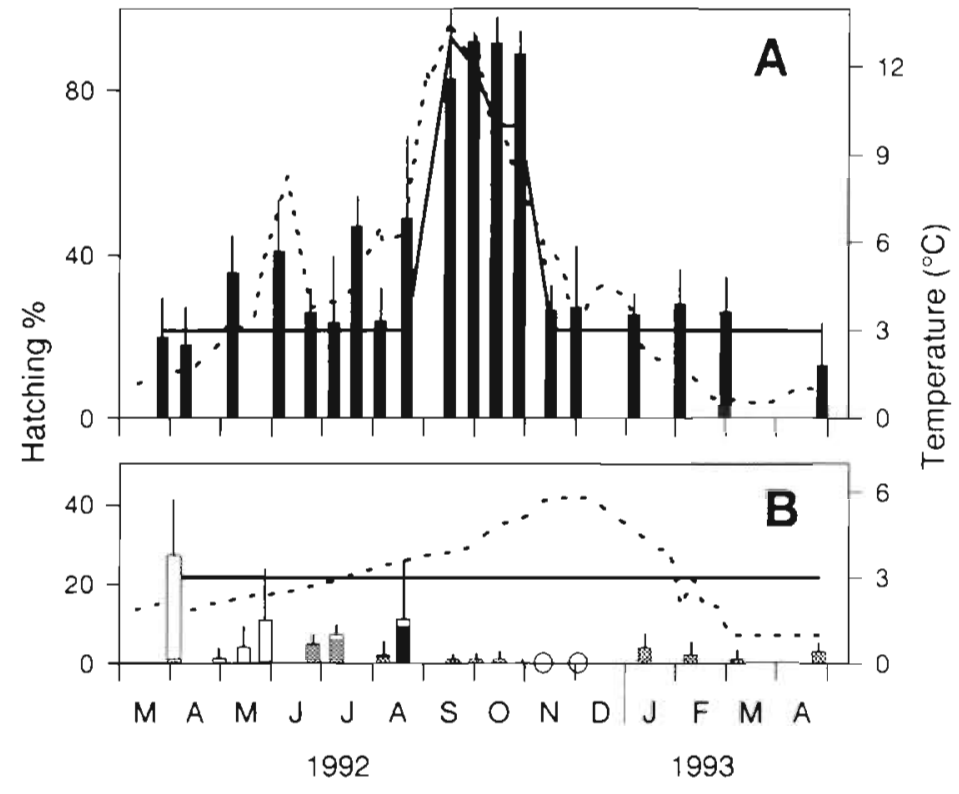

Fig. 6. Calanoida spp. Hatching of eggs sorted from the surface sediment ( 1 to $2 \mathrm{~cm}$ thick) at (A) Storfjärden ('red' eggs, Acartia bifilosa) and (B) Sällvik in 1992 and 1993. Means and standard deviations of 5 replicates, -50 eggs each. Stacked bars in (B): proportion of Acartia spp. (black), Eurytemora affinis (grey) and unidentified nauplii (white) among hatchlings. (O) Hatching percentage $0 \%$. Incubation temperature and ambient bottom water temperature indicated with continuous and dotted lines, respectively

The 'white' eggs from Storfjärden had a much lower hatching percentage than the 'red' eggs, 2 to $10 \%$ at $\geq 10^{\circ} \mathrm{C}$ (September to October) and $0 \%$ at $3^{\circ} \mathrm{C}$ (November to April). Of the 48 hatched nauplii, 29 were identified as Acartia spp. and 6 as Eurytemora affinis (the rest were not identified). After the last incubation in the spring of 1993 the plates were kept for another $6 \mathrm{~d}$ at $13^{\circ} \mathrm{C}$, during which time most of the eggs, both 'red' and 'white', hatched. Both Acartia spp. and E.

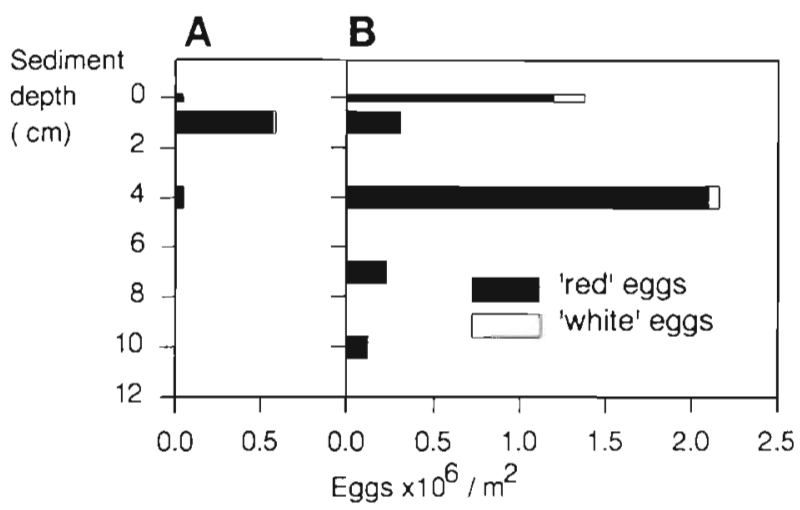

Fig. 7. Calanoida spp. Egg abundance estimates at 0, 1, 4,7 and $10 \mathrm{~cm}$ sediment depths at (A) Lăngskär and (B) Storgadden in May 1995. The ' $0 \mathrm{~cm}$ ' abundances are for thin surface layers, siphoned from the top of the cores, and are thus not comparable to the other abundances, representing $1 \mathrm{~cm}$ thick layers affinis were among the hatchlings from the 'white' eggs.

At Sällvik the bottom water temperature remained low and the incubations were run at $3^{\circ} \mathrm{C}$ throughout the study period (Fig. 6B). Hatching percentages were lower than for eggs from Storfjärden, and in November and December none of the eggs hatched in $6 \mathrm{~d}$. Of the hatchlings, $20 \%$ were Acartia spp. and $40 \%$ Eurytemora affinis (the rest were not identified). The highest percentage was attained on the first sampling occasion, when only 0 to $1 \mathrm{~cm}$ was sampled, which may have accounted for the result.

The eggs isolated from the 2 extra sediment cores in 1995 (Storgadden \& Långskär) were mainly of the 'red' type (Acartia bifilosa) (Fig. 7) and these 'red' eggs were used almost exclusively in the incubations. Among the total of 700 hatchlings, only 6 were Eurytemora affinis nauplii; the rest were Acartia spp. The hatching percentage was high for the surface eggs and declined with depth, at Storgadden more rapidly than at Långskär. On the other hand, the eggs were more abundant at Storgadden at all depths than at Långskär. The mean development time (in days) varied between $7.6 \pm 1.2( \pm \mathrm{SD})$ and $9.8 \pm 1.5$ at $3^{\circ} \mathrm{C}$, between $1.6 \pm 0.7$ and $2.5 \pm 0.8$ at $13^{\circ} \mathrm{C}$, and between $1.3 \pm$ 0.4 and $1.7 \pm 0.8$ at $18^{\circ} \mathrm{C}$ (Fig. 8). Treatments with fewer than 20 hatched eggs were omitted from these statistics. The final hatching percentage was not dependent on temperature.

\section{DISCUSSION}

\section{Benthic-pelagic coupling}

Our data suggests that benthic-pelagic coupling is important in the life cycle of Acartia spp. on the shallow coasts of the Baltic Sea. A large proportion of the eggs spawned by females seemed to reach the bottom prior to hatching, indicated by the correlations between the numbers of Acartia spp. females, benthic eggs and Acartia spp. nauplii at Storfjärden (Table 1). Egg abundance in the sediment clearly followed the variation in abundance of the planktonic females and was in turn followed by the naupliar abundance in the water column. The wide range in the lag periods was probably caused by the fact that development is slower in cold water in spring than in warmer temperatures in summer. In addition, egg production and survival as well as the egg stage duration in the sediment may vary seasonally and between species. 


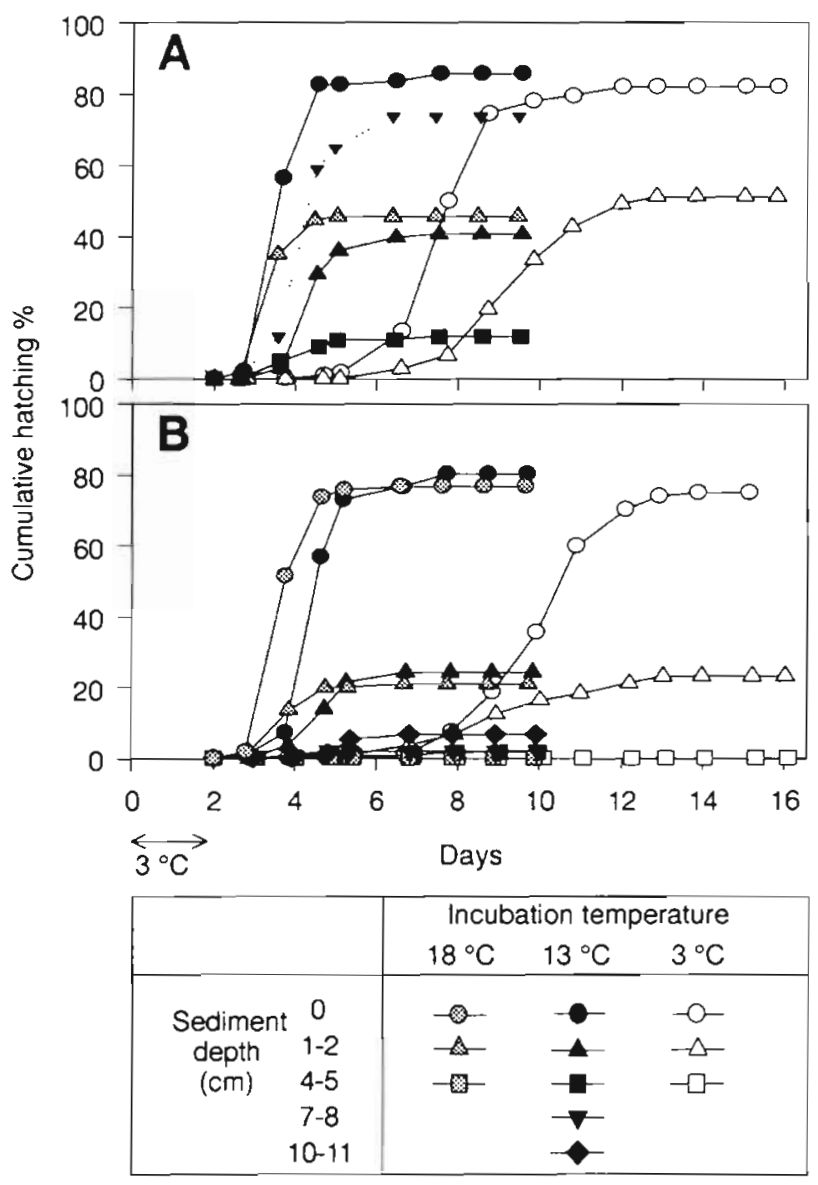

Fig. 8. Calanoida spp. Cumulative hatching of eggs from different sediment depths at (A) Långskär and (B) Storgadden incubated at different temperatures. Dotted line (Långskär 7 to $8 \mathrm{~cm}$ ): $\mathrm{N}=34$; others $\mathrm{N} \geq 74$

Other studies have made similar observations comparing the seasonal variation in egg abundance in the sediment and in plankton populations (Kasahara et al. 1975b, Uye 1982). Sinking of Acartia clausi eggs to the bottom prior to hatching in shallow areas was proposed by Landry (1978) and Uye (1980). Hatching from the bottom was also suggested by Ueda (1987), who observed that the first naupliar stages of $A$. hudsonica and A. omorii were always concentrated near the bottom, irrespective of the egg distribution in the water column. Sinking to the bottom prior to hatching has not been proposed earlier for the copepods of the Baltic Sea.

Estimates of the sinking velocity of marine calanoid eggs vary between 13 and $72 \mathrm{~m} \mathrm{~d}^{-1}$ (Landry 1978, Uye 1980, Marcus \& Fuller 1986, Kiørboe et al. 1988, Miller \& Marcus 1994). Thus, in less than $2.5 \mathrm{~d}$ the eggs would reach the bottom in areas shallower than $30 \mathrm{~m}$ even if released into the water near the surface. The egg development time was determined at several temperatures for Acartia bifilosa in July 1995: after being laid, the eggs hatched in $3 \mathrm{~d}$ at $\geq 12^{\circ} \mathrm{C}$ (Katajisto unpubl. data). These are comparable temperatures to the summer surface temperatures at Storfjärden (from June to September), but for most of the summer this warm layer is restricted to the upper 5 to $15 \mathrm{~m}$ (Niemi 1975, this study). Therefore, most eggs may sink to the bottom prior to hatching. However, turbulence and water currents may keep the eggs in the water column for a longer time than can be predicted solely from the sinking speed (Miller \& Marcus 1994).

At Sällvik the situation was different from that at Storfjärden. Acartia spp. were not very abundant and the data do not show a similar coupling between the planktonic and the benthic populations. All planktonic stages peaked on the same sampling dates, which indicates that the occurrence of the population may more likely be due to drifting with water bodies than to the development of the stages at the site. Eurytemora affinis differs from Acartia spp. in being able to prevent 'accidental' sedimentation of eggs by carrying them in an egg sac until hatching.

\section{Hatching of different egg types}

The eggs of Acartia bifilosa ('red' eggs) were found in sediments at Storfjärden throughout the year, and they hatched when incubated at ambient temperatures. This suggests that their dormancy is of the 'quiescent' type (cf. Grice \& Marcus 1981). In addition to the northern Baltic Sea, resting eggs of $A$. bifilosa have only been reported from Jiazhou Bay, China, with no reference to their type of dormancy (Zhong \& Xiao 1992).

The development rate of copepod eggs is closely temperature related (e.g. McLaren et al. 1969). Low temperature may also induce and maintain dormancy in the subitaneous eggs of some species (Johnson 1980). The eggs of Acartia bifilosa hatched equally well at all temperatures within the range found in the field $\left(1.5\right.$ to $\left.18^{\circ} \mathrm{C}\right)$, only the development rate varied according to temperature (Katajisto unpubl. data, this study). At $13^{\circ} \mathrm{C}$, the eggs hatched in 3 to $4 \mathrm{~d}$, so the $6 \mathrm{~d}$ incubations were long enough to reveal the 'final hatching' of the eggs. In contrast, at $3^{\circ} \mathrm{C}$, incubations for 12 to $14 \mathrm{~d}$ would be needed to accomplish the same. The seasonally varying hatching observed in this study thus refers not to the 'state' or viability of the eggs, but rather to the rate of the nauplii emergence from the sediment surface during different times of the year.

We suggest that the hatching of Acartia bifilosa nauplii from the sediment surface occurs more or less continuously throughout the year. The magnitude of emergence is dependent on the bottom temperature, which affects the development rate of the eggs, and on the size of the benthic egg pool close to the sedimentwater interface, where the eggs are subject to hatching 
or resuspension. If environmental conditions are suitable in the water column, the nauplii will survive and give rise to a new generation. Unsynchronized emergence from the bottom enables species to 'sample' different environmental conditions of the year (Johnson 1980, De Stasio 1990). At Storfjärden the benthic eggs hatched most intensively in autumn, when the water column was mixed to the bottom and warming of the deep water accelerated egg development. Resuspension of sediments may also have occurred during the mixing event. In an analysis of a long term data series from 1973 to 1984 a correlation between naupliar abundance in autumn and deep water temperature was detected (Viitasalo et al. 1994). This supports the conclusion that recruitment to a planktonic population at least seasonally depends on the processes affecting hatching from benthic eggs. In the autumn of 1992, most of the nauplii died before reaching the later stages but a small fraction survived, overwintered and may have developed into adults early in the spring.

At Storfjärden the 'white' eggs (Acartia tonsa and Eurytemora affinis) hatched at much lower rates than the 'red' ones. In Narragansett Bay (Rhode Island, USA) eggs of $A$. tonsa remain dormant at low temperatures $\left(\leq 6^{\circ} \mathrm{C}\right)$ and hatching is suppressed at intermediate temperatures $\left(9\right.$ to $15^{\circ} \mathrm{C}$ ) (Zillioux \& Gonzalez 1972, Sullivan \& McManus 1986). Such a dormancy pattern would explain the 'white' egg hatching results at Storfjärden, assuming that most of the eggs belonged to $A$. tonsa. In the southern Baltic Sea, Arndt \& Schnese (1986) state (without showing the data) that $A$. tonsa hatch from resting eggs at $>10^{\circ} \mathrm{C}$. As $A$. tonsa females were only observed in the autumn, the species may spend most of the year as benthic resting eggs, which hatch when the bottom water warms up in late summer. However, $A$. tonsa was also abundant at Sällvik, where the bottom water temperature did not rise above $6^{\circ} \mathrm{C}$ during the study year. As the peak abundance of Acartia spp. adults in autumn was not preceded by high juvenile abundances, the hatching of the benthic eggs and the development of the population may have taken place in the shallower surroundings of the Sällvik deep. On the other hand, strategies of dormancy within species may vary a great deal geographically (Marcus 1984b, Uye 1985); in California, A. tonsa eggs were able to hatch at $5^{\circ} \mathrm{C}$ (Uye \& Fleminger 1976).

The history of Acartia tonsa in the northern Baltic Sea is somewhat obscure. The species immigrated into European waters in the early 1900 s and it has become a permanent and abundant inhabitant of many estuarine habitats (Brylinski 1981). It was reported from the Gulf of Finland in 1935 (Smirnov 1935), but it has only occasionally occurred in plankton samples in the coastal northern Baltic Sea. However, $A$. tonsa was recently reported to occur in great numbers in the eastern Gulf of
Finland, where its abundance in the deep-water areas in autumn may reach 40 to $50 \%$ of the total copepod abundance (Silina 1991). In mesozooplankton monitoring samples from Storfjärden in 1966 to 1984, A. tonsa was rare (Viitasalo 1992b). There are no reports on zooplankton communities from Sällvik since that of Halme (1958), who did not distinguish between Acartia spp. The situation in 1992 seems to hold for later years too: A. tonsa females have been abundant in Storfjärden and Sällvik also in later autumns (Katajisto pers. obs.).

Eurytemora affinis has been shown to produce diapause eggs in a lake in Japan (Ban \& Minoda 1991). Thus far, only indirect evidence of diapause egg production by $E$, affinis exists from the Baltic Sea (Katajisto 1996). This could explain why no eggs hatched in the incubations from Sällvik in November and December. Towards the end of the year the sediment would be expected to be packed with diapause eggs if they were a means of overwintering. Also, the rise in benthic egg abundance in November could be due to deposition of the diapause eggs.

\section{Egg burial}

The study sites differ in several characteristics, which may have a significant effect on the benthic eggs. The higher sedimentation rate (A.-S. Heiskanen, Finnish Environment Agency, unpubl. data) and lower deep water temperature (leading to slower development) at Sällvik increase the probability of burial as compared with Storfjärden. After burial, the eggs may be transported back to the sediment surface if the sediment is bioturbated by benthic fauna (Marcus 1984a, Marcus \& Schmidt-Gengenbach 1986). Bioturbation mixes the sediment deeper than physical forces (e.g. Sanford 1992) and it also makes the sediment more susceptible to resuspension (Rhoads \& Young 1970). Although benthic animals may also be responsible for burying the eggs, the net effect of bioturbative particle transport in sediments is thought to be upwards (Håkansson \& Jansson 1983). Thus, at Sällvik the eggs have a high probability of burial and a low probability of returning to the sediment surface to hatch because the macrofauna is absent. On the other hand, at Storfjärden egg burial should be slower, and mixing of the sediments by the bottom dwelling fauna would provide a means of getting the buried eggs back to the surface. However, the predatory effects of the benthic fauna might overrun the positive effects of bioturbation. Copepod eggs may survive passage through polychaete guts (Marcus 1984a, Marcus \& Schmidt-Gengenbach 1986), but Monoporeia affinis, for example, is not able to ingest copepod egg sized particles without crushing them (Ankar 1977, Elmgren et al. 1986). 
The different egg abundance and viability profiles at Storgadden and Långskär in 1995 also reflect the differences between the sites. The Storgadden sediment was black and apparently anoxic, possibly resulting in a rapid decrease in viability with depth, whilst at Långskär the sediment type was brown clay. The reduced final hatching percentage of eggs in the deeper sediment layers may reflect a loss of viability over time, or it may simply be caused by a proportional increase in the originally unviable eggs in the sediments as the viable egg pool becomes smaller due to hatching. However, these results are only applicable to the eggs of Acartia bifilosa, since they were the dominant egg type in the sediments and in the incubations. Though the 'white' (A. tonsa and Eurytemora affinis) eggs do not contribute significantly to the total egg pool in the sediments, they may represent a larger fraction of viable eggs. E. affinis has been shown to remain viable for a decade in the seemingly anoxic sediments of Sällvik (Katajisto 1996).

\section{Conclusion}

We suggest that benthic resting stages play a significant role in the life cycles of the 3 most important copepod species in the northern Baltic coastal areas. Acartia bifilosa spawns freely in the water and, depending on the hydrographical conditions, a number of the eggs fall to the bottom. Some eggs hatch throughout the year either right from the sediment surface or after being resuspended to the water column. A. tonsa forms high population densities in late summer or autumn and it probably spends most of the year as benthic resting eggs, which hatch in late summer when bottom water warms up. Eurytemora affinis carries its eggs in an egg sac, thus reducing their probability of sinking to the bottom. It probably also produces diapause eggs that help to initiate the population again in spring. A. bifilosa and $E$. affinis occur in the plankton throughout the winter in low numbers. They thus have 2 possible sources of recruitment when conditions are again favourable for population growth in spring: hatching of benthic eggs and reproduction by the overwintering population.

Acknowledgements. We thank the staff of Tvärminne Zoolog ical Station, especially T. Sjölund, M. Pokki, U. Sjolund and S Degerholm for help with sampling and for providing the CTD data. S. Saesmaa identified the Acartia females to species. F Chen translated the main parts of the paper by Zhong and Xiao from the Chinese. Comments on the manuscript by S. Jonasdottir, T. Kiorboe, I. Vuorinen and 4 anonymous reviewers are gratefully acknowledged. The English was revised by L. Häkli This study was financed by the Academy of Finland, the Maj and Tor Nessling Foundation, the Walter and Andrée de Nottbeck Foundation and the Finnish Institute of Marine Research

\section{LITERATURE CITED}

Ankar S (1977) The soft bottom ecosystem of the northern Baltic proper with special reference to the macrofauna. Contrib Askö Lab (Stockholm) 19:1-62

Arndt $H_{1}$ Schnese $W$ (1986) Population dynamics and production of Acartia tonsa (Copepoda: Calanoida) in the Darss-Zingst estuary, southern Baltic. Ophelia Suppl 4: 329-334

Ban S, Minoda T (1991) The effect of temperature on the development and hatching of diapause and subitaneous eggs in Eurytemora affinis (Copepoda: Calanoida) in Lake Ohnuma, Hokkaido, Japan. Bull Plankton Soc Japan, Spec Vol:299-308

Boero F (1994) Fluctuations and variations in coastal marine environments. PSZN I: Mar Ecol 15:3-25

Brylinski JM (1981) Report of the presence of Acartia tonsa Dana (Copepoda) in the harbour of Dunkirk (France) and its geographical distribution in Europe. J Plankton Res 3: $255-260$

De Stasio BT Jr (1990) The role of dormancy and emergence patterns in the dynamics of a freshwater zooplankton community. Limnol Oceanogr 35:1079-1090

Elgmork K, Nilssen JP (1978) Equivalence of copepod and insect diapause. Verh Int Verein Limnol 20:2511-2517

Elmgren R, Ankar S, Marteleur B, Ejdung G (1986) Adult interference with postlarvae in soft sediments: the Ponto poreia-Macoma example. Ecology 67:827-836

Fryxell GA (ed) (1983) Survival strategies of the algae. Cambridge University Press, Cambridge

Grice GD, Marcus NH (1981) Dormant eggs of marine copepods. Oceanogr Mar Biol Annu Rev 19:125-140

Håkansson L, Jansson M (1983) Principles of lake sedimentology. Springer-Verlag, Berlin

Halme E (1958) Planktologische Untersuchungen in der PojoBucht und angrenzenden Gewässern. IV. Zooplankton Ann Zool Soc Zool Bot 'Vanamo' 19:1-62

Johnson JK (1980) Effects of temperature and salinity on production and hatching of dormant eggs of Acartia californiensis (Copepoda) in an Oregon estuary. Fish Bull US 77:567-584

Kansanen PH, Jaakkola T, Kulmala S, Suutarinen R (1991) Sedimentation and distribution of gamma-emitting radionuclides in bottom sediments of southern Lake Päijänne, Finland, after the Chernobyl accident. Hydrobiologia 222:121-140

Karjala L, Lassig J (1985) Studies on the benthic macrofauna in the Tvärminne area, Gulf of Finland, 1964-1967 and 1973-1976. Acad Sci Estonian SSR, Inst Zool Bot, Hydrobiol Res 15:169-180

Kasahara S, Onbé T, Kamigaki M (1975a) Calanoid copepod eggs in sea-bottom muds. III. Effects of temperature, salinity, and other factors on the hatching of resting eggs of Tortanus forcipatus. Mar Biol 31:31-35

Kasahara S, Uye S, Onbé T (1975b) Calanoid copepod eggs in sea-bottom muds. II. Seasonal cycles of abundance in the populations of several species of copepods and their eggs in the Inland Sea of Japan. Mar Biol 31:25-29

Katajisto T (1996) Copepod eggs survive a decade in the sediments of the Baltic Sea. Hydrobiologia 320:153-159

Kiørboe T, Møhlenberg F, Tiselius P (1988) Propagation of planktonic copepods: production and mortality of eggs. Hydrobiologia 167/168:219-225

Landry MR (1978) Population dynamics and production of a planktonic marine copepod, Acartia clausii, in a small temperate lagoon on San Juan Island, Washington. Int Rev Ges Hydrobiol 63:77-119 
Lindley JA (1992) Resistant eggs of the Centropagoidea (Copepoda: Calanoida): a possible preadaptation to colon nization of inland waters. J Crust Biol 12:368-371

Lindström M, Nilsson HL (1988) Eye function of Mysis relicta Lovén (Crustacea) from two photic environments. Spectral sensitivity and light tolerance. J Exp Mar Biol Ecol 120: $23-37$

Marcus NH (1984a) Recruitment of copepod nauplii into the plankton: importance of diapause eggs and benthic processes. Mar Ecol Prog Ser 15:47-54

Marcus NH (1984b) Variation in the diapause response of Labidocera aestiva (Copepoda: Calanoida) from different latitudes and its importance in the evolutionary process. Biol Bull (Woods Hole) 166:127-139

Marcus NH (1989) Abundance in bottom sediments and hatching requirements of eggs of Centropages hamatus (Copepoda: Calanoida) from the Alligator Harbor region, Florida. Biol Bull (Woods Hole) 176:142-146

Marcus NH, Fuller CM (1986) Subitaneous and diapause eggs of Labidocera aestiva Wheeler (Copepoda: Calanoida): differences in fall velocity and density. J Exp Mar Biol Ecol 99:247-256

Marcus NH, Schmidt-Gengenbach J (1986) Recruitment of individuals into the plankton: the importance of bioturbation. Limnol Oceanogr 31:206-210

McLaren IA, Corkett CJ, Zillioux EJ (1969) Temperature adaptations of copepod eggs from the arctic to the tropics. Biol Bull (Woods Hole) 137:486-493

Miller DD, Marcus NH (1994) The effects of salinity and temperature on the density and sinking velocity of eggs of the calanoid copepod Acartia tonsa Dana. J Exp Mar Biol Ecol $179: 235-252$

Niemi $\AA$ (1973) Ecology of phytoplankton in the Tvärminne area, SW coast of Finland. I. Dynamics of hydrography, nutrients, chlorophyll a and phytoplankton. Acta Bot Fenn 100:1-68

Niemi $\AA$ (1975) Ecology of phytoplankton in the Tvärminne area, SW coast of Finland. II. Primary production and environmental conditions in the archipelago and the sea zone. Acta Bot Fenn 105:1-73

Niemi $\AA$ (1978) Ecology of phytoplankton in the Tvärminne area, SW coast of Finland. III. Environmental conditions and primary production in Pojoviken in the 1970s. Acta Bot Fenn 106:1-28

Omori M, Ikeda $T$ (1984) Methods in marine zooplankton ecology. John Wiley and Sons, New York

Onbé T (1978) Sugar flotation method for sorting the resting eggs of marine cladocerans and copepods from sea-bottom sediment. Bull Jap Soc Scient Fish 44:1411

Onbé T (1985) Seasonal fluctuations in the abundance of populations of marine cladocerans and their resting eggs in the Inland Sea of Japan. Mar Biol 87:83-88

Reid PC, John AWG (1978) Tintinnid cysts. J Mar Biol Assoc UK 58:551-557

Revsbech NP, Sørensen J, Blackburn TH, Lomholt JP (1980) Distribution of oxygen in marine sediments measured with microelectrodes. Limnol Oceanogr 25:403-411

Rhoads DC, Young DK (1970) The influence of deposit-feeding organisms on sediment stability and community trophic structure. J Mar Res 28:150-178

Sanford LP (1992) New sedimentation, resuspension, and burial. Limnol Oceanogr 37:1164-1178
Silina NI (1991) Current condition of the zooplankton of the eastern Gulf of Finland. Oceanology 31:447-450

Smirnov SS (1935) Über das Auftreten von Acartia tonsa Dana (Copepoda) im Finnischen Meerbusen. CR (Doklady) Acad Sci URSS 3:237-240

Stigzelius J, Laine A, Rissanen J, Andersin AB, Ilus E (1997) The introduction of Marenzelleria viridis (Polychaeta, Spionidae) into the Gulf of Finland and the Gulf of Bothnia (northern Baltic Sea). Annls Zool Fenn 34:205-212

Sullivan BK, McManus LT (1986) Factors controlling seasonal succession of the copepods Acartia hudsonica and $A$. tonsa in Narragansett Bay, Rhode Island: temperature and resting egg production. Mar Ecol Prog Ser 28:121-128

Ueda $H$ (1987) Small-scale ontogenetic and diel vertical distributions of neritic copepods in Maizuru Bay, Japan. Mar Ecol Prog Ser 35:65-73

Uye S (1980) Development of neritic copepods Acartia clausi and A. steueri. I. Some environmental factors affecting egg development and the nature of resting eggs. Bull Plankton Soc Japan 27:1-9

Uye S (1982) Population dynamics and production of Acartia clausi Giesbrecht (Copepoda: Calanoida) in inlet waters J Exp Mar Biol Ecol 57:55-83

Uye S (1985) Resting egg production as a life history strategy of marine planktonic copepods. Bull Mar Sci 37:440-449

Uye S, Fleminger A (1976) Effects of various environmental factors on egg development of several species of Acartia in southern California. Mar Biol 38:253-262

Uye S, Kasahara S, Onbé T (1979) Calanoid copepod eggs in sea-bottom muds. IV. Effects of some environmental factors on the hatching of resting eggs. Mar Biol 51:151-156

Viitasalo M (1992a) Calanoid resting eggs in the Baltic Sea: implications for the population dynamics of Acartia bifilosa (Copepoda). Mar Biol 114:397-405

Viitasalo M (1992b) Mesozooplankton of the Gulf of Finland and northern Baltic proper - a review of monitoring data. Ophelia 35:147-168

Viitasalo M, Katajisto T (1994) Mesozooplankton resting eggs in the Baltic Sea: identification and vertical distribution in laminated and mixed sediments. Mar Biol 120: $455-465$

Viitasalo M, Katajisto T, Vuorinen I (1994) Seasonal dynamics of Acartia bifilosa and Eurytemora affinis (Copepoda: Calanoida) in relation to abiotic factors in the northern Baltic Sea. Hydrobiologia 292/293:415-422

Watson NHF, Smallman BN (1971a) The role of photoperiod and temperature in the induction and termination of an arrested development in two species of freshwater cyclopid copepods. Can J Zool 49:855-862

Watson NHF, Smallman BN (1971b) The physiology of diapause in Diacyclops navus Herrick (Crustacea, Copepoda). Can J Zool 49:1449-1454

Williams R, Collins NR (1986) Seasonal composition of meroplankton and holoplankton in the Bristol Channel. Mar Biol 92:93-101

Zhong X, Xiao Y (1992) Resting eggs of Acartia bifilosa Giesbrecht and A. pacifica Steuer in Jiaozhou Bay. Mar Sci (Qingdao) 5:55-59 (in Chinese with English summary)

Zillioux EJ, Gonzalez JG (1972) Egg dormancy in a neritic calanoid copepod and its implications to overwintering in boreal waters. In: Battaglia B (ed) Fifth European Marine Biology Symposium. Piccin editore, Padova, p 217-230

Submitted: March 25, 1996; Accepted:December 1, 1997

proofs received from author(s): February 9, 1998 